Bernd C. Peyer/Wolfgang Lindig

\title{
Jack Forbes
}

Of Powhatan descent, Jack Forbes is one of the leading intellectual figures in contemporary Native American affairs. He has been directly involved in numerous political actions such as the Alcatraz Takeover, the Trail of Broken Treaties and the Longest Walk and has served as advisor in matters of community level politics throughout the West Coast area. He is largely responsible for the establishment of Native American Studies (NAS) departments on several campuses in California and he is also one of the originators and founders of D-Q University, an all-Native American institution of higher learning located some seven miles outside of Davis, Ca. Forbes is the author of a large number of articles and books such as Apache, Navajo, and Spaniard (1960), The Indian in America's Past (1964), Warriors of the Colorado (1965), Nevada Indians Speak (1967), Native Americans of California and Nevada (1969), Aztecas del Norte (1973), and Die Wétiko-Seuche (1981).

Forbes is professor of anthropology at the University of California in Davis and is currently on a Fulbright Professorship in England. The following article was written in view of the fact that the Bureau of Indian Affairs is working on a new definition for federal recognition of Native Americans and has called for outside suggestions on that subject. 